\title{
A review of the Andrarum Limestone and the upper alum shale (Middle Cambrian) of Bornholm, Denmark
}

\author{
VIVIANNE BERG-MADSEN
}

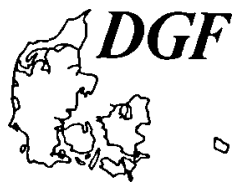

Berg-Madsen, V.: A review of the Andrarum Limestone and the upper alum shale (Middle Cambrian) of Bornholm, Denmark. Bull. geol. Soc. Denmark, vol. 34, pp. 133-143. Copenhagen, December, 19th, 1985. https://doi.org/10.37570/bgsd-1985-34-12

\begin{abstract}
The lithology and fossil content of the Middle Cambrian Andrarum Limestone on Bomholm is briefly reviewed. Trilobites, brachiopods and hyolithids are common, acid residues contain a rich fauna of pelagiellaceans, rostroconchs and echinoderm fragments. Most of these are phosphatized with well preserved micro- and ultrastructures. A revised list of trilobites is presented. New finds of trilobites in the lowermost upper alum shale show the lower part of the Lejopyge laevigata Zone to be no more than $10 \mathrm{~cm}$ thick. The occurrence of the Upper Cambrian conodont Westergaardodina tricuspidata permits a more exact placement of the Middle-Upper Cambrian boundary. The Middle Cambrian deposits are shown to be $3 \mathrm{~m} \pm 10$ $\mathrm{cm}$ in total thickness in the two localities known on Bornholm.
\end{abstract}

Vivianne Berg-Madsen, Paleontologiska Institutionen, Box 558, S-751 22 Uppsala, Sweden. November 21st, 1984. Present address: Geological Institute, Stockholm University, Box 6801, S-10691, Sweden.

\section{Introduction}

Except for the lower Middle Cambrian of Sweden and Norway, the Middle Cambrian of Baltoscandia is usually developed as black shale facies with two significant limestone units. These units - the Exsulans and Andrarum limestones are found at several localities throughout Scandinavia. Even when the limestones are absent, their characteristic trilobite fauna occurs in the black shales and correlation is possible.

This paper presents a preliminary study of the Andrarum Limestone microfossils, whereas the trilobites are only discussed briefly. The microfauna is less diversified than that found in the Exsulans Limestone/Kalby marl (Berg-Madsen, 1981) but rostroconchs, some pelagiellaceans and echinoderms appear for the first time and details of their individual micro- and ultrastructure are in many cases extermely well preserved.

Information from new fossil occurrences in the upper alum shale permits location of the MiddleUpper Cambrian boundary to $0.7 \mathrm{~m}$ (Læså) and $1.6 \mathrm{~m}$ (Øleå) above the Andrarum Limestone, within a succession of black shales $(26 \mathrm{~m})$.

\section{Previous investigations}

Forchhammer (1835) was the first to describe the geology of Bornholm including the CambrianSilurian lithology and fossils, although only very superficially. However, he noted the Middle Cambrian alum shale and its associated limestone beds as well as the use of the limestone for a certain type of strong cement due to the clay content. From this, it is evident that he described the Andrarum Limestone, its name first coming to use much later (Angelin 1854, Nathorst 1869). Thus, Seebach (1865) still used the term Regio Conocorypharum of Angelin when he described his visit to Bornholm. Regio Conocorypharum roughly corresponds to the Paradoxides forchhammeri beds, whereas the $P$. paradoxissimus beds were placed in Regio Olenorum and by that means incorrectly placed in the stratigraphical succession. This knowledge helps in the interpretation of Seebach whose locality descriptions are repeatedly inaccurate and confusing.

Johnstrup $(1874,1891)$ made the first detailed description of the Palaeozoic of Bornholm. He listed 23 species of trilobites, brachiopods and 
hyolithids from the Andrarum Limestone without specifying the locality (Læså or Øleå). Although his collecting methods were dubious and have long caused stratigraphical problems (BergMadsen, 1985), his determinations from the Andrarum Limestone and overlying alum shale are generally correct.

Grönwall $(1899,1902)$ investigated the Middle Cambrian thoroughly. Johnstrup's list was repeated and several new species added. The overlying upper alum shale yielded only very few fossils as did the anthraconite (stinkstone) lenses. Both the shale and the lenses were described as extremely hard. This was confirmed by C. Poulsen (1923) who estimated the position of the Middle-Upper Cambrian boundary on the presence of a presumed ostracode, Svealuta primordialis, at $0.8 \mathrm{~m}$ (Middle Cambrian) and the agnostid trilobite Agnostus pisiformis at $2.1 \mathrm{~m}$ above the Andrarum Limestone at Øleå. As the agnostid A. pisiformis is also found in the Middle Cambrian Lejopyge laevigata Zone (Table 2), the value of its occurrence in delimiting the Upper Cambrian in this case is debatable.

Hansen (1945) described the Middle and Upper Cambrian rocks of Bornholm lithologically as did Hadding (1958). Apart from short reviews by C. Poulsen (1960) and V. Poulsen (1966), neither the Andrarum Limestone nor the Middle Cambrian upper alum shale have been investigated for fossils. More attention has been drawn to the Middle Cambrian limestones in general with regard to their diagenetic changes reflected in their ${ }^{13} \mathrm{C} /{ }^{12} \mathrm{C}$ and ${ }^{18} \mathrm{O} /{ }^{16} \mathrm{O}$ isotope compositions (BergMadsen 1981, 1985, Buchardt \& Nielsen 1985).

\section{Methods}

About $6 \mathrm{~kg}$ Andrarum Limestone were crushed into pieces and dissolved in $10 \%$ acetic acid. Due to the clay content the dissolution was very slow. In order to avoid unnecessary etching or total dissolution of the fossils, the pieces were regularly examined under a binocular microscope. Thus three stages of collecting have been maintained: 1) pure limestone pieces with macrofossils, 2) partly dissolved limestone containing macro- and microfossils on the surfaces, and 3) microfossils picked manually from the insoluble residue. The residue consists of a more or less coherent spongy mass of clay and bituminous matter which had to be broken before picking under a binocular microscope. 40 samples of upper alum shale, each covering a $10 \mathrm{~cm}$ level, were collected from bottom to top of the main profiles at Læså and Øleå. Each sample on average weighted $1.5 \mathrm{~kg}$. Cleaned, broken samples were examined under a binocular microscope.

\section{The Andrarum Limestone}

Laeså. - The Andrarum Limestone is exposed at two well known localities: the rivulet Læså near
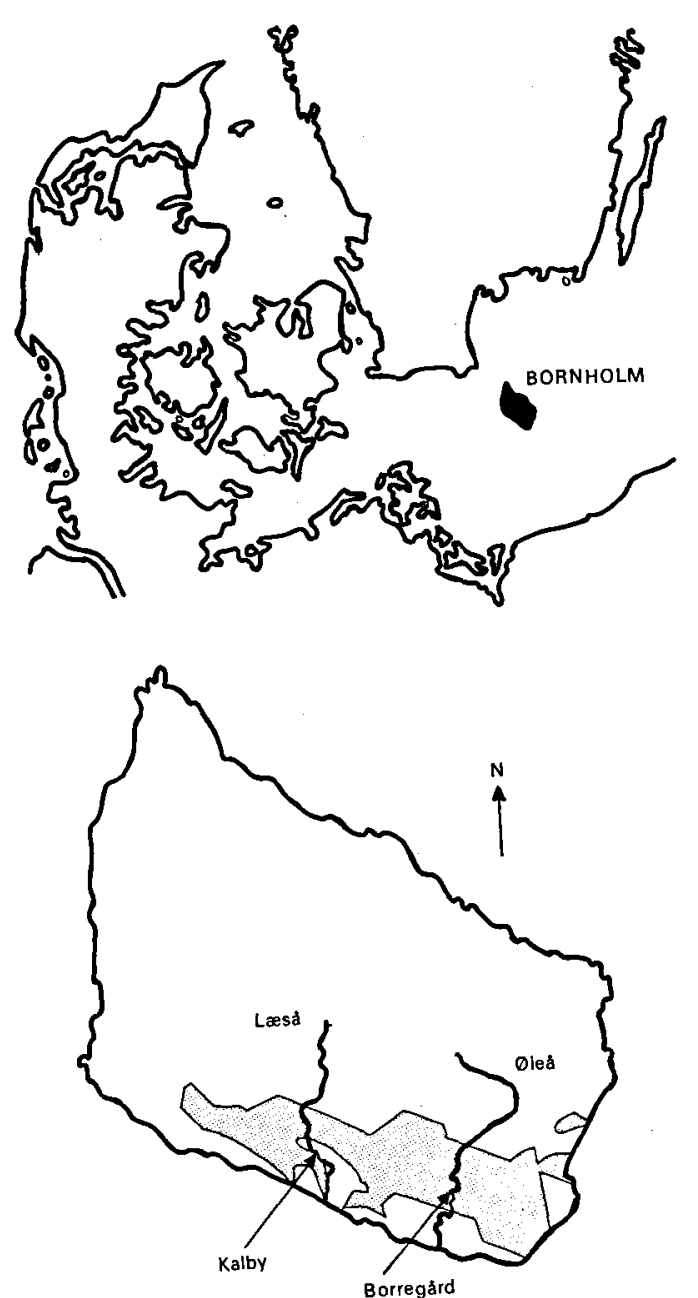

Fig. 1. Map of Bornholm showing the sub-Quaternary distribution of Cambrian rocks (stippled) and the position of Kalby and Borregård. 


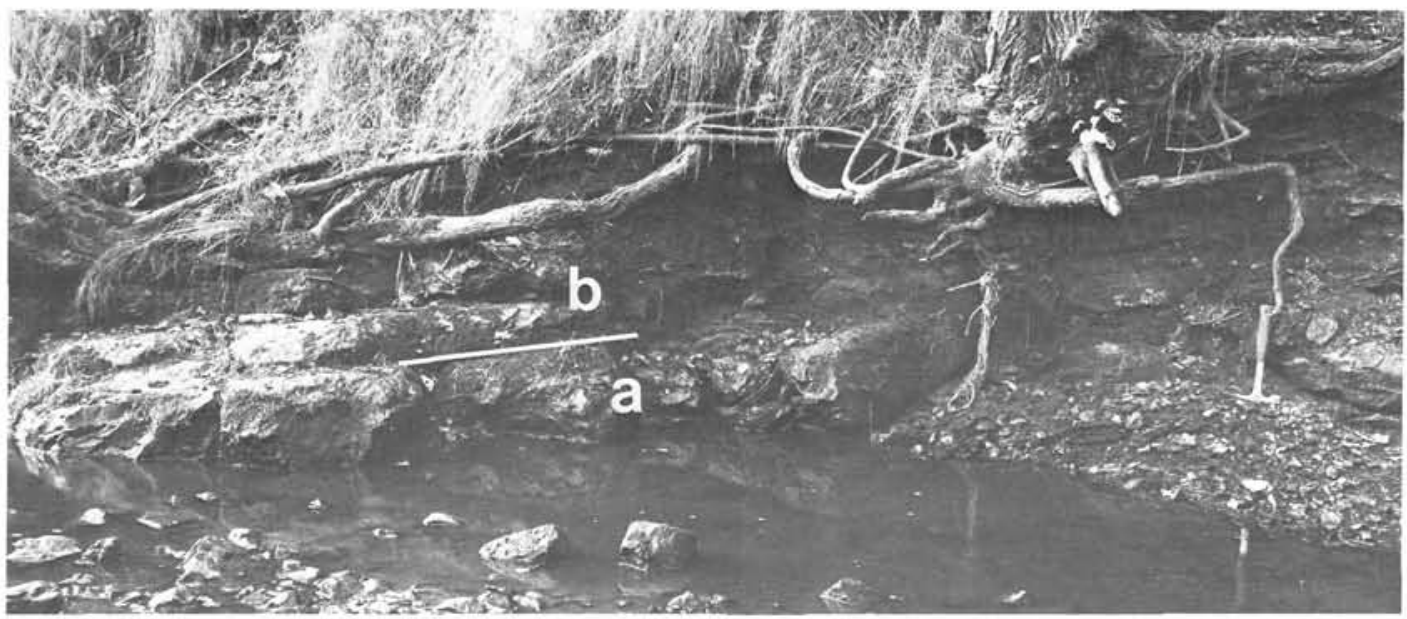

Fig. 2. The Middle part of the main exposure at Laså. The Hyolithes limestone (a) is overlain by Andrarum Limestone (b), the strata dipping below the water level to the left. The same part of the exposure is figured in Hansen (1945, fig. 9, p. 22). Photograph: A. Philip.

the Kalby farms and the rivulet Øleå at Borregård farm (Fig. 1). At Læså it crops out in the right bank of the rivulet and can be followed for more than $20 \mathrm{~m}$. Due to the dip of the strata most of the exposure occurs in the stream bed. The limestone overlies the Hyolithes limestone (Fig. 2 ), from which it is separated by a thin layer of "fragment limestone" (Hadding 1958, Berg-Madsen 1985). Immediately overlying is the upper alum shale. The Andrarum Limestone is heavily weathered and almost devoid of calcium carbonate where it overlies the Hyolithes limestone and the Kalby marl in the northeren part of the exposure. Except for the weathered part, the Andrarum Limestone is extremely hard and difficult to break due to the combination of clay $(>25 \%)$ and calcium carbonate.

Øleå. - The exposure at Øleå is a former cement quarry where the limestone can be followed for $25 \mathrm{~m}$ at the main exposure. The strata are almost horizontal (Fig. 3) and the exposure shows the almost complete Middle Cambrian sequence. The basal Middle Cambrian Exsulans Limestone is seen in the stream bed near the right bank. The basal anthraconite is absent here and the lower alum shale forms the remaining stream bed and the base of the cliff. As already noticed by Johnstrup $(1874,1891)$, the thickness of the lower alum shale at this exposure hardly exceeds $0.1 \mathrm{~m}$. Overlying the lower alum shale, the Hyolithes limestone is found just above the average water level, separated from the Andrarum Limestone by $10-30 \mathrm{~mm}$ of alum shale. Overlying the Andrarum Limestone are more than $2.2 \mathrm{~m}$ of upper alum shale with anthraconite lenses. Johnstrup $(1874,1891)$ collected his samples at the former crushing mill $200 \mathrm{~m}$ WNW of the quarry, W of Borregård farm, because of the hardness of the limestone.

The thickness of the Andrarum Limestone varies between 0.5 and $0.7 \mathrm{~m}$; it is thickest at Øleå, and averages $0.6 \mathrm{~m}$ at both localities. It should be noted, though, that the Hyolithes limestone is included in older literature where the thickness averages $0.8 \mathrm{~m}$ (Grönwall, 1902).

Lithology, - Two different lithological developments can be distinguished: (1) dark grey and fine grained limestone and (2) light grey and coarse grained limestone. The dark grey limestone is compact and the single calcite grains are coated by bitumen and clay minerals. Pyrite and phosphorite occur. The light grey crystalline parts contain quartz and glauconite grains. The latter are similar to the moulds of inorganic origin found in the Exsulans Limestone/Kalby marl and thus regarded as authigenic glauconite (Berg-Madsen, 1983). The Andrarum Limestone on Bornholm differs from that of the type locality in Scania (Skåne) by its content of quartz, glauconite and phosphorite (Hadding, 1958). The phosphorite occurs as diffuse bodies or aggregates rather than in discrete lumps and nodules. 


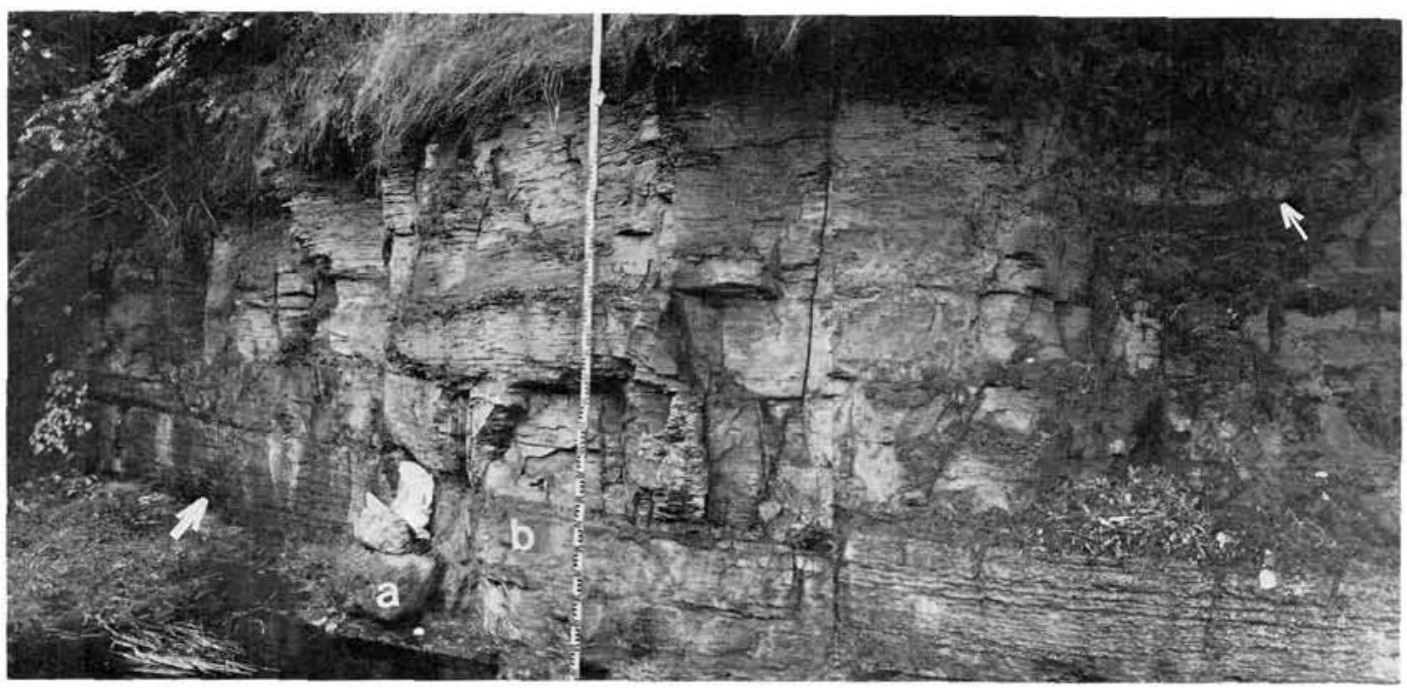

Fig. 3. The eastern part of the main exposure at Øleã. The thick arrow (lower left) indicates large scale cross-bedding, the thin arrow (upper right) at the cavity left by an anthraconite lense. The middle part to the right of the levelling rod is also figured in Grönwall (1899, pl. 2) and Hansen (1945, fig. 6, p. 15). Photograph: A. Philip.

Phosphorite is most common in the upper part of the unit and is often associated with microfossils. An analysis (EDAX) of the insoluble residue showed 39.9 wt. \% Si, 26 wt.\% Al (enriched),
$13.5 \mathrm{wt} \% \mathrm{Mg}, 6.2 \mathrm{wt} \% \mathrm{~K}, 4.5 \mathrm{wt} . \% \mathrm{Fe}$ and 2.6 $\mathrm{wt} \% \mathrm{P}$ as the main constituents. Large gypsum crystals recorded by Grönwall (1902) have not been found in the present investigation.

\begin{tabular}{ll}
\hline protaspis sp. indet. & Paradoxides forchhammeri \\
Agraulos aculeatus & Solenopleura brachymetopa subsp. indet. \\
A. acuminatus & S. b. alutacea \\
A. difformis & S. bucculenta \\
Anomocare laeve & S. canaliculata \\
Anomocarina excavata subsp. indet. & S. holometopa subsp. indet. \\
A. e. dentata & S. h. humilis \\
A. extomata & Grandagnostus glandiformis \\
Anomocarioides limbatus & Hypagnostus brevifrons \\
Bailiaspis glabrata & H. exsculptus \\
Centropleura loveni & Lejopyge laevigata \\
C. steenstrupi & L. Zundgreni \\
Dasometopus breviceps & Peronopsis fallax ferox \\
Eccaparadoxides sjoegreni nepos & P. f. minor \\
Elyx laticeps & P. quadrata \\
Groenwallia microphthalma & Phalagnostus bituberculatus \\
G. platyrohina & Ptychagnostus aculeatus
\end{tabular}

Table 1. The trilobite fauna of the Andrarum Limestone on Bornholm compiled after Johnstrup (1891), Grönwall (1902) and finds by the author. Revised after Westergård (1946, 1948, 1953a), Jago (1976), and Robison (1984). 


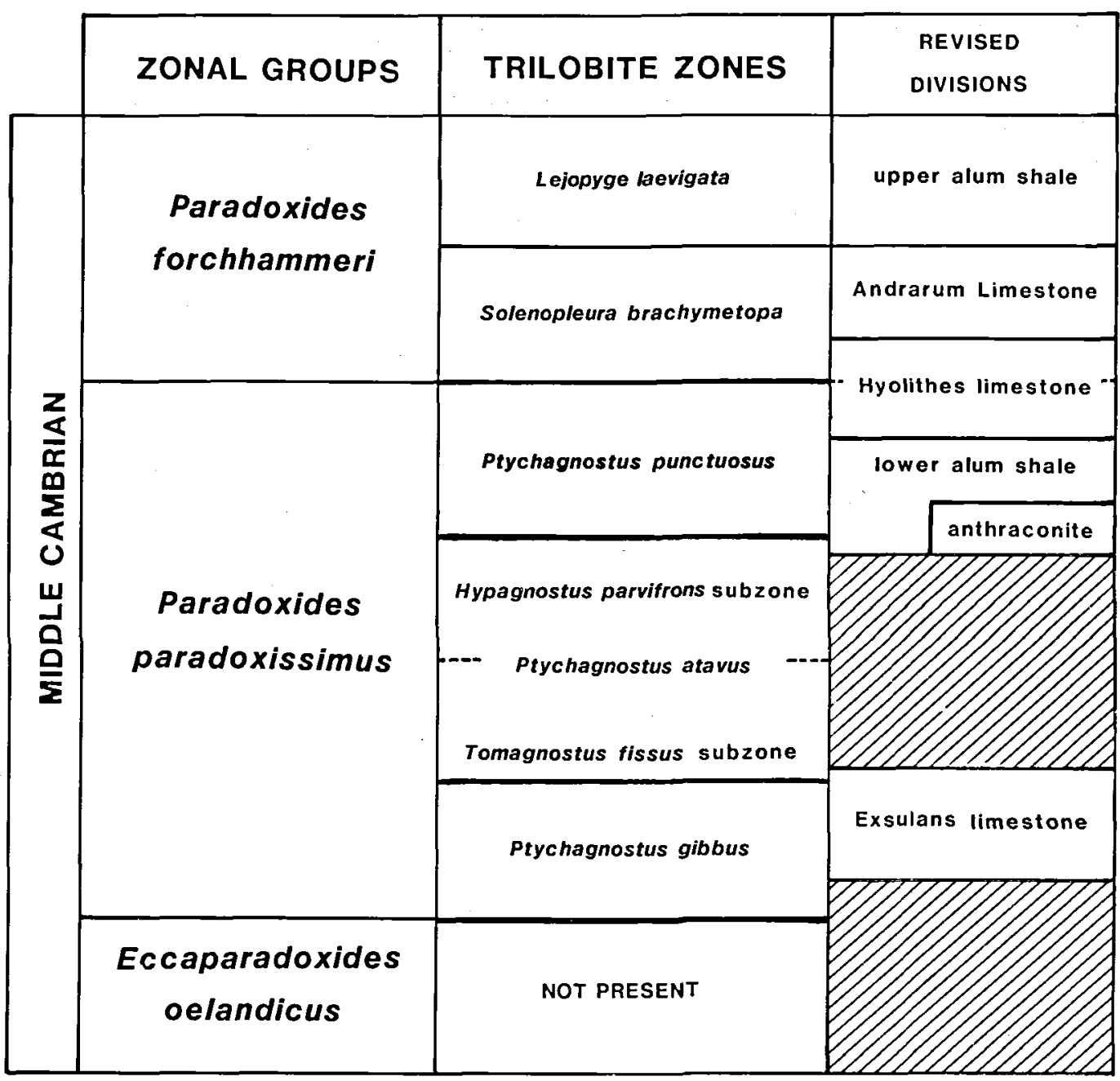

Table 2. The Middle Cambrian stratigraphy of Bornholm (after Berg-Madsen, 1985).

Bedding within the limestone unit has not been observed in thin sections or on larger polished sections. Not even the fossils can be related to specific levels but occur scattered or as minor concentrations in certain parts of the unit but are absent in other parts. However, bedding and large scale cross bedding can be recognized on eroded surfaces at the quarry at $\emptyset$ leå (Fig. 3).

The Andrarum Limestone is a primary marine deposit as opposed to the diagenetic limestone beds (basal anthraconite and Hyolithes limestone) and lenses (Buchardt \& Nielsen, 1985).

Fossil content. - trilobites have been used as the basis for correlation (Westergård 1946, 1948, $1950,1953 a)$. A revised list of trilobites is pre- sented in Table 1. Most of the trilobites listed here are restricted to the zone of Solenopleura brachymetopa (Table 2) to which the Andrarum Limestone and at least the upper part of the Hyolithes limestone belong (Berg-Madsen, 1985). The Bornholm fauna is limited when compared with the 80 trilobite species known from the type locality at Andrarum in Skåne. Some species are even endemic to Bornholm.

The large hyolithid Hyolithes tenuistriatus was recorded by Johnstrup $(1874,1891)$ and the determination was confirmed by Holm (1893). Additional specimens have not been found but fragment of hyolithids are common.

Inarticulate brachiopods' were studied by See- 
bach (1865) who described Acrotreta socialis, whose identity has remained somewhat obscure. Linnarsson (1876) selected some type specimens from the Andrarum Limestone on Bornholm in his description of Palaeozoic brachiopods from Sweden. Johnstrup $(1874,1891)$ and Grönwall $(1899,1902)$ recorded mostly the same species as Linnarsson. Walcott (1912) included all the described species in his monograph on Cambrian brachiopods and tried to elucidate the problematic Acrotreta socialis. C. Poulsen (1942) described species new to Bornholm from the Exsulans Limestone/Kalby marl from where a number of new species is known to be present. This also goes for the Andrarum Limestone (Bassett \& Berg-Madsen, unpublished results). Acrotretids, acrothelids and lingulellids occur, but $\mathrm{Mi}$ cromitra and Dictyonina are among the most commonly occurring genera (Figs. 4A-C).
Minute phosphatic and glauconitic internal moulds referrable to pelagiellaceans are common, especially in the phosphatic bodies in the upper part of the unit. Stopping dissolution at an early stage, it was possible to obtain moulds partly imbedded in the matrix together with imprints or remnants of the surrounding shell. In Fig. 5G the internal mould forms only the first part of the first whorl. The gap between the mould suggests at two-layer shell. Thus the here shown extremely thin, phosphatic layer may represent the inner part of the outer layer (Figs. $5 \mathrm{G}, \mathrm{I})$. Occasionally more complete moulds occur (Fig. $5 \mathrm{H}$ ) with the outer shell layer attached and freed from the matrix. The shell ornament is extremely well preserved and clearly indicates a different species from that of Grönwall (1902). Grönwall compared his species (Fig. 5J) with material found and described by Brøgger (1878) as

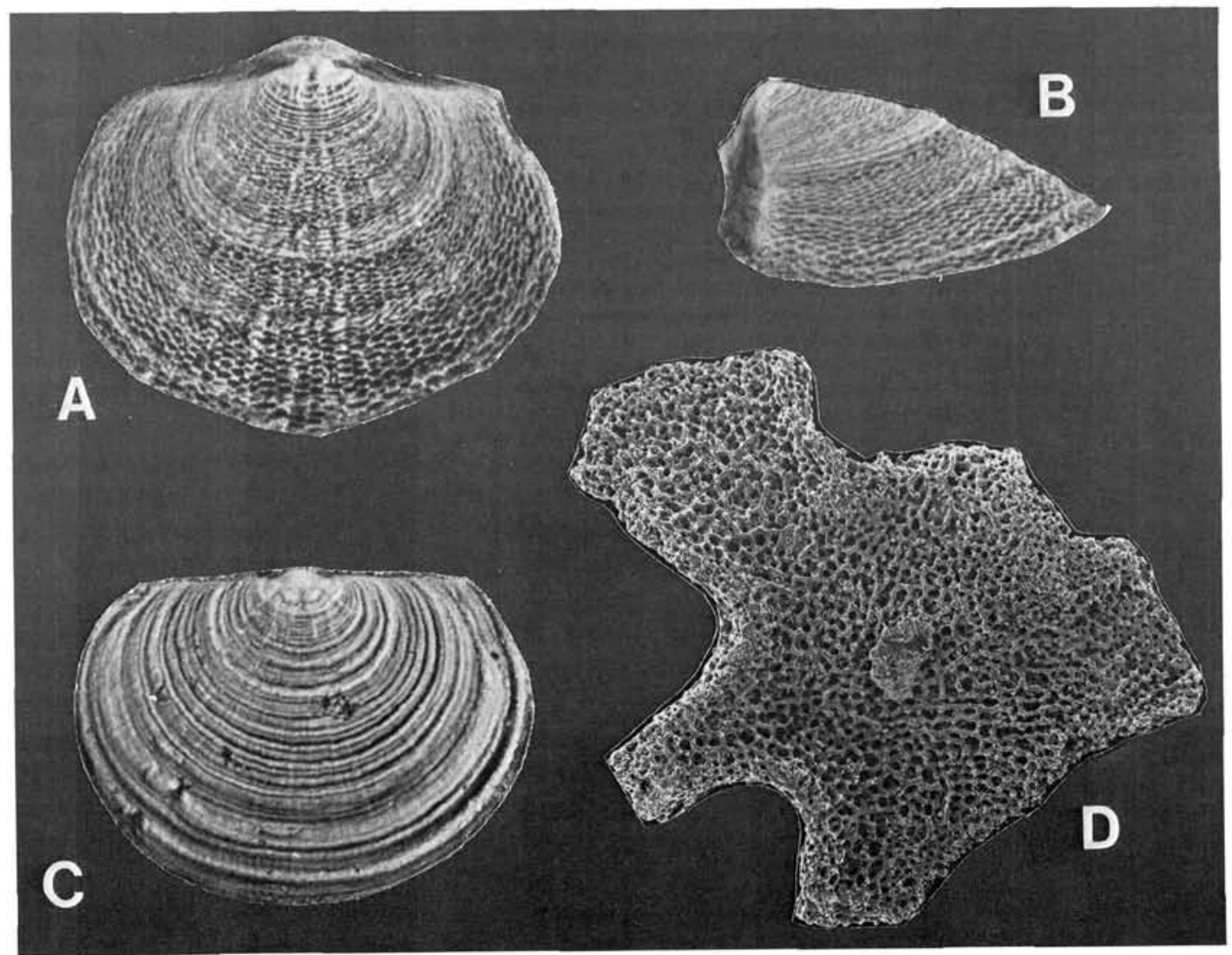

Fig. 4. A Dictyonina $\mathrm{sp}$. , pedicle valve $\times 15$. B. As A, lateral view $\times 15$. C. Micromitra $s p$, brachial valve $\times 15$. D. Dorsal plate of cornute stylophoran $\times 80$. Photographs A-C: M. G. Bassett, D: T. Westberg. 


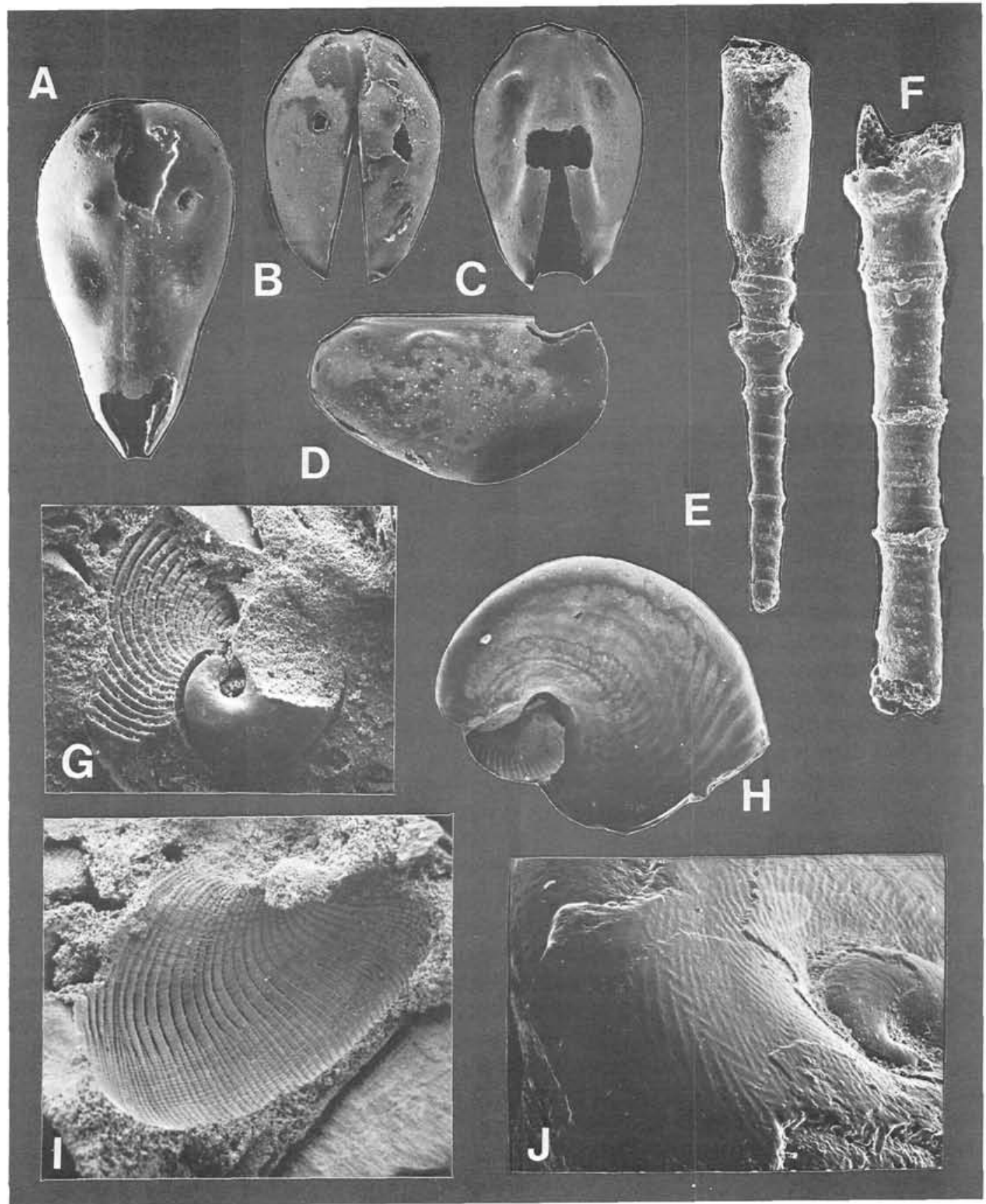

Fig. 5. A. Hesslandonid ostracode in dorsal view showing straight double hinge $\times 70$. B. Same, posterior view $\times 70$. C. Same, anterior view $\times 70$. D. Same, right lateral view $\times 70$. E. Internal mould of a tube with almost complete shaft and chamber $\times 50$. F. Shaft broken at both ends $\times 80$. G. Pelagiellacean internal mould with partial impression of the shell $\times 70 . \mathrm{H}$. Complete internal mould with adhering piece of (outer?) shell freed from the matrix $\times 60$. I. Imprint of shell in phosphatized matrix $\times 70$. J. Pelagiella (Parapelagiella kreklingensis) (Grönwall), MMH 203, detail of shell $\times 110$. Photographs A-D, G-J: J. Fuglsang, E-F: T. Westberg. 
gastropod sp. indet. Brøgger's species, however, is conspecific with the present material that I have collected.

Rostroconchs are generally rare in the Middle Cambrian (Pojeta \& Runnegar, 1976) and have not been recorded previously from the Middle Cambrian of Baltoscandia. The Andrarum Limestone yielded about 50 fragments of at least two ribeiriids, but without more and better preserved specimens, a more exact determination is impossible.

Ostracodes are rare, the few specimens found can be referred to the Hesslandonidae. The figured specimen (Figs. 5A-D) is rather small and may be a new species but a closer generic assignment is impossible.

Small calcitic and phosphatized echinoderm fragments are fairly common. The best preserved calcitic fragments were obtained when the dissolution of the limestone was stopped at an early stage (see Methods). As with the echinoderm fragments from the Exsulans Limestone/Kalby marl a reconstruction is not possible. Some of the fragments can be referred to eocrinoids and cornute stylophorans. Most phosphatized fragments show beautiful preservation of the stereom structure (Fig. 4D). Stem ossicles with different types of articulation, also known from the Exsulans Limestone/Kalby marl, are of special interest as these have not been recorded previously (BergMadsen, 1986).

Conodonts are not uncommon but contrary to the Exsulans Limestone/ Kalby marl (Berg-Madsen, 1981) Gapparodus bisulcatus exceeds Amphigeisina sp. in number. The latter is similar to $A$. danica but much more slender. Specimens of $G$. bisulcatus are also larger, up to $2.5 \mathrm{~mm}$ in length and a maximum of $0.3 \mathrm{~mm}$ in width.

A few specimens of Lapworthella bornholmiensis have been found. Their presence in the Andrarum Limestone represents the highest stratigraphic level yet recorded. Primarily the genus occurs in the Lower Cambrian.

Spicules of Protospongia fenestrata, Chancelloria eros and cf. Hintzespongia, as well as unidentified sponge spicules, occur scattered throughout the unit. C. eros is occasionally found in the form of glauconitic moulds similar to the occurrence in the Exsulans Limestone/Kalby marl and preferentially in the lower part of the unit. In the diffuse phosphatic bodies in the up- per levels clumps built from masses of miscellaneous spicules are found. These superficially resemble part of a tridimensional skeleton (J. K. Rigby, Provo, Utah; personal communication 1984).

Small, phosphatic internal moulds of tubes (Figs. 5E-F) are common. They consist of a thin "shaft" with a ring-like ornamentation of alternating thickness ending in a wide chamber with a smooth surface. Usually the chamber is filled with clay and bituminous matter but empty chambers occur. These internal moulds are occasionally found inside small conical tubes (hyolithids?) of calcite with a surface ornamentation of tiny growth lines. In cross section the internal as well as the external tubes are circular. The nature of the specimens is unknown, but $\mathrm{E}$. $\mathrm{L}$. Yochelson (Washington, D. C.; personal communication 1981) found no resemblance to either Volborthella or Salterella.

In addition to the above mentioned large fossil groups problematic fossil fragments are commonly found.

\section{The upper alum shale}

Laså. - The main exposure of the lower (Middle Cambrian) part of the upper alum shale is above the weathered part of the Andrarum Limestone. A minor exposure crops out where the Andrarum Limestone dips below the water level in the rivulet. The thickness is $0.85-0.9 \mathrm{~m}$, and the topmost part of the alum shale is covered with overhanging soil and vegetation. Anthraconite lenses are not found at Læså.

Øleå. - The Middle Cambrian part of the upper alum shale has its main exposure corresponding to that of the Andrarum Limestone (Fig. 3). At this exposure the maximum thickness of beds previously assigned to the Middle Cambrian is $2.1 \mathrm{~m}$. An anthraconite lense (sensu stricto) immediately overlies the Andrarum Limestone and the cavity left by another lense occurs $1.3 \mathrm{~m}$ above the limestone (Fig. 3).

Lithology. - In spite of the weathering of the limestones in the northernmost part of the exposure at Læså, the upper alum shale is surprisingly unaffected. The fissility is good, but rather thick $(\geq 5 \mathrm{~cm}$ ) and massive levels occur. A level about $10 \mathrm{~cm}$ above the top of the weathered Andrarum 
Limestone contains small nodules of partly weathered limestone, $3-5 \mathrm{~cm}$ in diameter. At $\varnothing$ lea the weathering of the shale is much more pronounced. The covering by jarosite is not limited to the outer part of the exposures but is also found on the bedding planes. The fissility is good, and the shales cleave into paper-thin pieces. Bedding plane surfaces are more uneven at Øleå than at Læså. The shale is black compared with the dark grey lower alum shale. Illite is the predominant clay mineral, and pyrite occurs finely dispersed throughout the sequence. In contrast to the lower alum shale quartz grains are extremely rare. Small, less than $2 \mathrm{~mm}$, rosettes of flat gypsum crystals are common on the bedding planes.

Fossil content. - Several previous authors (Johnstrup 1874, 1891, Grönwall 1899, 1902, C. Poulsen 1923, Hansen 1945, V. Poulsen 1966) have commented that fossils are rare in the Middle Cambrian upper alum shale. The present investigation has shown the shale to be more fossiliferous than supposed. Trilobites are rare and mostly represented by fragments of pleurae. In the lowermost $10 \mathrm{~cm}$ above the Andrarum Limestone one agnostid found in the shale has been determined as Peronopsis insignis. The nodules forming the top of this level have yielded Acrocephalites stenometopus. Both species here mentioned have a range within the zone of Lejopyge laevigata but are found only at the top of the zone (Wallerius 1895, Westergård 1946, 1948). Thus, the lower part of the zone on Bornholm is represented by less than $10 \mathrm{~cm}$ of strata. This coincides well with the type locality in Skane where $A$. stenometopus is recorded from a level $30 \mathrm{~cm}$ above the Andrarum Limestone (Westergård 1948). Only about $4 \mathrm{~m}$ of upper alum shale is here regarded as Middle Cambrian, and the topmost $3 \mathrm{~m}$ are unfossiliferous (Moberg 1910, Westergård 1946).

Inarticulate brachiopods are abundant in the lowermost $40 \mathrm{~cm}$, especially at Læså, but occur throughout the whole section. Micromitra is the most common genus and has not been found higher than $1.5 \mathrm{~m}$ above the Andrarum Limestone at Øleå (65 cm at Læså). Acrotretids and lingulellids also occur.

Svealuta primordialis, the large $(9 \mathrm{~mm})$ presumed ostracode, has been found at Læså $0.3 \mathrm{~m}$ above the Andrarum Limestone. C. Poulsen
(1923) recorded the same species from Øleå, from a level $0.8 \mathrm{~m}$ above the limestone, but here it has now been found as high as $1.2 \mathrm{~m}$. A small, ( $<2 \mathrm{~mm}$ long) hesslandonid ostracode with spines at the posterior-ventral rim of the valves is found at the same level as $\boldsymbol{S}$. primoridalis at Læså, while minute indeterminate species occur at slightly lower levels.

Whereas Svealuta primordialis and Micromitra are restricted to the Middle Cambrian, none of the other species are stratigraphically significant. Neither is the conodont Gapparodus bisulcatus which occurs as flattened specimens in the lowermost levels. Important, though, is the presence of Westergaardodina tricuspidata which is first known from the Upper Cambrian zone of Agnostus pisiformis (Westergård 1953b, Müller 1959, 1971). The preservation in generally poor although the characteristic $M$ shape always is recognizable. Mostly they stand out as thin films on the bedding surfaces, some appear as cavities filled with charred organic matter. Cambrian conodonts are rather thin and do not sustain heat, in this case as a result of the deep burial diagenesis (Buchardt \& Nielsen, 1985).

Grönwall $(1899,1902)$ recorded Lejopyge laevigata from anthraconite lenses and shale above the Andrarum Limestone at Læså. Lenses are not known from this locality today, and the lense immediately overlying the Andrarum Limestone at Øleå has not been investigated for fossils. Apart from the finds by Grönwall, Lejopyge laevigata has not been recorded in connection with recent investigations (V. Poulsen, Inst. Hist. Geol. \& Pal., Copenhagen; personal comm. 1984).

\section{The Middle-Upper Cambrian boundary on Bornholm}

C. Poulsen (1923) placed the Middle-Upper Cambrian boundary somewhere between 0.8 and $2.1 \mathrm{~m}$ above the Andrarum Limestone from fossils found at the exposures at Øleå. The boundary is here now placed between $1.5 \mathrm{~m}$ (Micromitra, Middle Cambrian inarticulate brachiopod genus) and $1.6 \mathrm{~m}$ above the Andrarum Limestone on the basis of the first occurrence of the Upper Cambrian conodont Westergaardodina tricuspidata. 
At Læså Micromitra is found no higher than $0.6 \mathrm{~m}$ above the Andrarum Limestone, whereas $W$. tricuspidata occurs at the $0.7 \mathrm{~m}$ level. Consequently the boundary is placed no higher than this level at Læså.

The maximum thickness of the Middle Cambrian on Bornholm has been estimated to be 4-5 $\mathrm{m}$ (V. Poulsen, 1966). This computed figure was based on the cumulative maximum thickness of each stratum. However, the maximum thickness of all strata is nowhere to be seen together. The identical thickness $3 \mathrm{~m} \pm 10 \mathrm{~cm}$ at both Læså and $\emptyset$ leå is coincidental. The lower alum shale, for example, is $1.4 \mathrm{~m}$ thick at Laså and only 10-15 $\mathrm{cm}$ thick at the main exposure at Øleå. The maximum thickness from another exposure at Øleå $(0.8 \mathrm{~m})$ was recorded by Grönwall (1899) but here it was overlain neither by the Hyolithes limestone nor the Andrarum Limestone.

None of the described modifications induce any stratigraphical changes. Thus the revised Middle Cambrian stratigraphy (Table 2) is to be regarded as definitive (Berg-Madsen, 1985).

Acknowledgements. I am grateful to colleagues and friends for critical reading and comments. In particular to: J. S. Peel (Geol. Survey of Greenland, Copenhagen), M. G. Bassett (National Mus. of Wales, Cardiff) and my thesis advisor E. T. Alexandersson (Dept. of Quaternary Geol., Uppsala). J. Berg. ström (Geol. Survey of Sweden, Lund) also identified and confirmed the trilobite material, J. K. Rigby (Dept. of Geol., Brigham Young Univ., Provo, Utah) described the sponges. Special thanks also to A. Philip for help in the field with collecting and photography. T. Westberg (Pal. Inst., Uppsala) and J. Fuglsang (Geol. Inst., Copenhagen) did the SEM and other photographic work. Financial support was received from the Swedish Natural Science Research Council (NFR) grant No. 3045-111. This is a contribution to Project Tornquist (IGCP Accession No. 86).

\section{Dansk sammendrag}

Den Mellem Kambriske Andrarumkalk på Bornholm er undersøgt specielt med henblik på mikrofaunaen. Denne er artsfattigere end den fra den noget aldre Exulanskalk og Kalbymergel, men bevaringstilstanden er undertiden meget bedre. Dette gælder ikke mindst mikro- og ultrastruktuerne hos blandt andet pelagiellaceer og echinodermer. En generel oversigt over de fundne grupper bliver givet, eftersom en mere detaljeret beskrivelse i flere tilfæilde er under udarbejdelse. En revideret liste over trilobiter kendte fra Andrarumkalken på Bornholm præsenteres. Den inkluderer også nye fund. Den øvre alunskiffers nederste $2 \mathrm{~m}$ har vist sig mere fossilrig end tidligere antaget. Fund af trilobiter har påvist, at den underste del af $\mathbf{L e j o}$ pyge laevigata Zonen næppe overstiger $10 \mathrm{~cm}$ i mægtighed. Dette modsvarer omtrentligt forholdene på typelokaliteten Andrarum i Skåne. Foruden trilobiter forekommer brachiopoder, ostracoder og conodonter. Forekomsten af en typisk mellemkambrisk brachiopod, Micromitra, og conodonten Westergaardodina tricuspidata, kun kendt fra $\emptyset$ vre Kambrium, fastlægger grænsen Mellem- Øvre Kabrium på et betydeligt lavere niveau end hidtil antaget. Samtidigt påvises også at magtigheden af Mellem Kambrium ikke er mere end $3 \mathrm{~m} \pm 10 \mathrm{~cm}$ på de to lokaliteter hvorfra blotninger er kendte. Denne magtighed ligger nær den kendt fra boringer.

Note added in proof: Lately about 10 fragments of a bivalve, assignable to Malletiidae, and a single specimen of Yochelsonella sp. have been obtained from the Andrarum Limestone.

\section{References}

Angelin, N. P., 1854: Palaeontologia Scandinavica, 1-92. Lund. Berg-Madsen, V., 1981: The Middle Cambrian Kalby and Borregård Members of Bornholm, Denmark. Geol. Föreningens i Stockholm Förhandl. 103 (2), 215-231.

Berg-Madsen, V., 1983: High-alumina glaucony from the Middle Cambrian of Öland and Bornholm, southern Baltoscandia. J. Sed. Petrol. 53 (3), 875-893.

Berg-Madsen, V., 1985: The Middle Cambrian of Bornholm, Denmark: A stratigraphical revision of the lower alum shale and associated anthraconites. Geol. Föreningens $i$ Stockholm Förhandl. 106 (4).

Berg-Madsen, V., 1986: Middle Cambrian cystoid (sensu lato) stem columnals from Bornholm, Denmark. Lethaia 19 (2) in press.

Berg-Madsen, V. \& Peel, J. S., 1978: Mjddle Cambrian monoplacophorans from Bornholm and Australia, and the systematic position of the bellerophontiform molluscs. Lethaia 11 (2), 113-125.

Brøgger, W. C., 1878: Om Paradoxidesskifrene ved Krekling. Nyt Magazin for Naturvidenskaberne 24 (1), 18-88.

Buchardt, B. \& Nielsen, A. T., 1985: Carbon and oxygen isotope composition of Cambro-Silurian calcareous rocks from Bornholm: Evidence for deep burial diagenesis. Bull. geol. Soc. Denmark 33, in press.

Forchhammer, J. G., 1835: Danmarks geognostiske forhold. Indbydelsesskrift til Reformationsfesten den 14de November 1835 i Kjøbenhavn, 1-121.

Grönwall, K. A., 1899: Bemærkninger om de sedimentære dannelser på Bornholm og deres tektoniske forhold. Danm. geol. Unders. II Række, 10, 1-52.

Grönwall, K.A., 1902: Bornholms Paradoxideslag og deres fauna. Danm. geol. Unders. II Række, 13, 1-230.

Hadding, A., 1958: Cambrian and Ordovician limestones. The pre-Quaternary sedimentary rocks of Sweden, VII. Lunds Universitets Ärsskrift N. F. 2 (54), 1-262.

Hansen, K., 1945: The Middle and Upper Cambrian sedimentary rocks of Bornholm. Danm. Geol. Unders. II Rakke, $72,1-81$.

Holm, G., 1893: Sveriges Kambrisk-Siluriska Hyolithidae och Conularidae. Sveriges geol. unders. C 112, 1-173.

Jago, J. B., 1976: Late Middle Cambrian agnostid trilobites from north-western Tasmania. Palaeontology 19 (1), 133172.

Johnstrup, F., 1874: Oversigt over de palæozoiske dannelser på Bornholm. Beretning llte skandinaviske naturforskerm $\phi d e$ i Kjøbenhavn 1873, 1-10.

Johnstrup, F., 1891: Abriss der Geologie von Bornholm, als Führer zu der Exkursion der Deutschen Geologische Gesellschaft der Insel Bornholm im Anschluss an die allgemeine Versammlung in Greifswald $1889.66 \mathrm{pp}$.

Linnarsson, G., 1876: Brachiopoda of the Paradoxides beds of Sweden. Bihang til Kungl. Sv. Vetenskaps-Akademiens handlingar 3 (12), 1-34. 
Moberg, J. C., 1910: Guide for the principal Silurian districts of Scania (with notes on some localities of Mesozoic beds). Geol. Föreningens $i$ Stockholm Förhandlingar 32 (1), 4561.

Müller, K. M., 1959: Kambrische Conodonten. Z. deutsch. geol. Ges. 111 (2), 434-485.

Müller, K. J., 1971: Cambrian conodont faunas. In Sweet, W. C. \& Bergström, S. M. (eds.): Symposium on Conodont Biostratigraphy. Geol. Soc. Am. Mem. 127, 5-20.

Nathorst, A. G., 1869: Om lagerföljden inom Cambriska formationen vid Andrarum i Skåne. Öfversigt. Kungl. Sv. Vetenskaps-Akademiens Förhandlingar 26 (1), 61-65.

Pojeta, J. \& Runnegar, B., 1976: The paleontology of rostroconch molluscs and the early history of the phylum Mollusca. Prof. Pap. U.S. Geol. Survey 968, 1-88.

Poulsen, C., 1923: Bornholms Olenuslag og deres fauna. Danm. geol. Unders. II Række, 40, 1-83.

Poulsen, C., 1942: Nogle hidtil ukendte fossiler fra Bornholms Exsulanskalk. Meddr. dansk geol. Foren. 10 (2), 212-235.

Poulsen, C., 1960: The Palaeozoic of Bornholm. XXI International Geological Congress, Guide to excursions nos. $A$. 46 and $C 41$. 1-15.

Poulsen, V., 1966: Cambro-Silurian stratigraphy of Bornholm. Meddr. dansk geol. Foren. 16 (2), 117-137.
Robison, R. A., 1984: Cambrian agnostids of North America and Greenland Part I, Ptychagnostidae. Univ. Kansas Pal. Contr. 109, 1-59.

Seebach, K. von, 1865: Beiträge zur geologie der Insel Bornholm. Z. deutsch. geol. Ges. 17, 338-347.

Walcott, C. D., 1912: Cambrian brachiopoda. U.S. Geol. Survey Monographs 51, 1-872, $104 \mathrm{pl}$.

Wallerius, I., 1895: Undersökningar ofver zonen med Agnostus laevigatus $i$ Vestergötland, Lund, $71 \mathrm{pp}$.

Westergård, A. H., 1946: Agnostidea of the Middle Cambrian of Sweden. Sveriges geol. unders. C 477, 1-141.

Westergård, A. H., 1948: Non-agnostidean trilobites of the Middle Cambrian of Sweden I. Sveriges geol. unders. C 498, 1-33.

Westergård, A. H., 1950: Non-agnostidean trilobites of the Middle Cambrian of Sweden II. Sveriges geol. unders. C $511,1-57$.

Westergård, A. H., 1953a: Non-agnostidean trilobites of the Middle Cambrian of Sweden III. Sveriges geol. unders. C $526,1-59$.

Westergård, A. H., 1953b: Two problematic fossils from the Cambrian of Sweden Geol. Föreningens $i$ Stockholm För. handlingar 75 (4), 465-468. 